Int. J. Morphol.,

31(4): 1459-1469, 2013.

\title{
Histological Analysis of the Reproductive System and Gonad Maturity of Octopus rubescens
}

\author{
Análisis Histológico del Aparato Reproductor y la Madurez Gonadal del Pulpo Octopus rubescens
}

López-Peraza, D. J."; Hernández-Rodríguez, M.*; Barón-Sevilla, B. * \& Bückle-Ramirez, L. F. *

LÓPEZ-PERAZA, D. J.; HERNÁNDEZ-RODRÍGUEZ, M.; BARÓN-SEVILLA, B. \& BÜCKLE-RAMIREZ, L. F. Histological analysis of the reproductive system and gonad maturity of Octopus rubescens. Int. J. Morphol., 31(4):1459-1469, 2013.

SUMMARY: This study described the reproductive system and gonadal development of Octopus rubescens from Bahía de Todos Santos, Baja California, Mexico. A total of 65 organisms, 35 males weighing 7.2 to $543.4 \mathrm{~g}$ and 30 females from 9.4 to $87.7 \mathrm{~g}$ where analyzed. The gonad development was defined through histological methods using Hematoxylin-eosin and Arteta- trichrome stains. We describe macroscopically the reproductive system of males and females, and characterized each of the anatomic components. Eight stages of maturity were recognized in females: 1. Immature, 2. Initial folliculogenesis, 3. Final folliculogenesis, 4. Previtelogenesis, 5. Early vitelogenesis, 6. Final vitelogenesis, 7. Maturing and 8. Spawn. In males five stages were identified: 1. Immature, 2. Maturing A, 3. Maturing B, 4. Mature type 1 and 5. Mature type 2. This work is the first histological description of the reproductive system of this species and the beginning for future research on its basic biology.

KEY WORDS: Octopus rubescens; Histology; Reproductive system; Gonad maturity.

\section{INTRODUCTION}

The cephalopod capture is an artisanal fishery along the coast that does not have a precise regulation of their populations and catches (Boyle \& Rodhouse, 2005). In México, according to the Carta Nacional Pesquera (CNP, 2010), the octopus fishery ranks fourth nationally for its high commercial value, surpassed by the shrimp, tuna and tilapia. This fishery is concentrated in the Gulf of Mexico and Caribbean Sea and affects Octopus vulgaris and Octopus maya, the latter species is endemic of the Yucatan Peninsula. In the North Pacific Ocean $O$. macropus, O. bimaculatus and $O$. hubbsorum are captured (SEMARNAP, 1999), although its contribution to national production is minor.

In recent years the study of the octopus has increased due to its high economic value and potentiality of its culture, because they are short-lived organisms with high growth rates (Iglesias \& Sanchez, 2007). In addition, they are an important source of food for human consumption with high protein content (75 to $85 \%$ of the dry weight of its body composition), approximately $20 \%$ more compared with the fish (Lee, 1994). In relation to the research of the reproductive biology of these organisms, few species have been studied and this information is necessary for the fishery resources management and the aquaculture development.
$O$. vulgaris, is one of the best known and most studied cephalopods in the world, mainly due to its wide distribution (Lang \& Hochberg, 1997), market demand and the status of wild populations (Petza et al., 2006). Several authors as Arkhipkin (1992), Khallahi \& Inejih (2002), Rodriguez-Rua et al. (2005) and Jiménez-Badillo et al. (2008), have established maturities scales for this species, based on scales reported by other authors, their own criteria and objectives of their research.

In O. mimus, Olivares-Paz et al. (2001), describe a maturity scale of nine stages for females and three stages for males. Price (1959) for the first time defines the reproductive system in $O$. bimaculoides excluding the histological description of the ovary and testis.

Another species that have been most studied are Eledone moschata and E. massay and a four stages scale has been established for both sexes (Ezzeddine-Najai, 1997; Álvarez-Perez \& Haimovici, 1991). Boyle \& Knobloch (1984) and Moriyasu (1988) recognized in E. cirrhosa a scale with three stages for females and males.

Octopus rubescens has a medium weight up to 1.5 $\mathrm{kg}$. His distribution comprises the southern part of the Gulf 
of California, Mexico to the Gulf of Alaska in USA. It is characterized by a triangle of white spots on the front of the head and the arms as well and two white spots on the dorsal medial region of the mantle. Female has an average fecundity of 20000 to $50000 \mathrm{eggs}, 3$ to $4 \mathrm{~mm}$ length, which grows to planktonic larvae (Lang \& Hochberg).

The extraction in the Pacific coast of this resource, without control, probably could lead to the population decrease. In addition, the actual knowledge of their basic biology is insufficient, knowledge that is considered of fundamental importance because it allows properly managing of the resource, starting with the search for new production options in order to meet the market demand. The aim of this study is to describe the reproductive system of $O$. rubescens and the different stages of gonad maturity in order to start further research and experimental culture.

\section{MATERIAL AND METHOD}

We captured a total of 65 individuals of $O$. rubescens, 36 males and 30 females in the Bahía de Todos Santos, BC, Mexico (31 ${ }^{\circ} 52^{\prime}$ Lat. N.; $116^{\circ} 37^{\prime}$ Long. O.). In the laboratory, octopuses were weighed and measured, then they were anaesthetized with an overdose of 2-phenoxyethanol $(0.3 \mathrm{ml}$ $\mathrm{L}^{-1}$ ). We removed the reproductive system, measured the width of the ovary in females and the length of the reproductive system in males, including the testes, the spermatophoric gland, the accessory spermatic gland, the spermatic duct and a section of the Needham's sac that were fixed in Davidson solution. The tissues were embedded in paraffin and sectioned at $4 \mu \mathrm{m}$ thickness of each organ, stained with Harris hematoxylin-eosin or with Arteta-trichrome (Valderrama et al., 2004). The tissues were analyzed using a Leica microscope, model DMRXA2 equipped with a digital camera of 36-bit and 3.3 megapixel (Leica, model DC300) and an Olympus microscope CKX41 equipped with an Olympus C-5060 camera. We identified and described macroscopic and histologically the reproductive system structures of male and female based on the description of Price for Octopus bimaculoides.

We recognized a maturity scale for $O$. rubescens based on the criteria established for $O$. vulgaris (Rodríguez-Rua et $a l$.) and $O$. mimus (Olivares-Paz et al.).

\section{RESULTS}

The range of weight for females was 9.4 to $87.7 \mathrm{~g}$, and mantle length of $24.5 \mathrm{~mm}$ to $59.4 \mathrm{~mm}$, and the males had a weight of 7.2 to $543.4 \mathrm{~g}$ and mantle length of 20.2 to $95 \mathrm{~mm}$, respectively.

Macroscopic description of the female reproductive system. The ovary membrane has a white color that with the progress of the maturity state turns yellow. The ventral region of the ovary has an opening forming a funnel that leads to a common oviduct, and then it split up giving origin to the proximal oviducts, parallel to the digestive gland toward the front of the mantle cavity. The final portion of the distal oviduct is open, allowing access to the spermatophores deposited by males that are storage in the oviductal glands until the female is ready to spawn.

Histological description of the female reproductive system. The membrane that surrounds the ovary is a fibrous tissue, mainly collagen. This membrane emerges projections or trabeculae of fibrous tissue in the form of branches within the ovary, where the germ cells and developing oocytes formes the ovarian stroma (Fig. 1A). The distal and proximal oviducts have smooth muscle fibers, fusiform and parallel to each other, with elongated central core. The lumen of the oviduct epithelium consists of ciliated cells (Fig. 1B).

Oviductal glands are constituted by various glandular tissues, which have a folding arrangement (Fig. 1C). These tissues have a contrasting color, which probably could be related to the type of substance they secrete; the central glandular tissue is hyaline and the one located at the periphery turns a deep red.

In a cross section of the central region of the gland, spermathecaes are observed. They are egg-shaped and consist of ciliated columnar epithelium with spherical nuclei located near the basal lamina (Fig. 1D).

We recognize eight sexual maturity stages (Fig. 2) based on cell types and their proportions, the thickness of the follicular layers of the oocytes, follicle invaginations, the presence of the chorion and postovulatory follicles and the oocytes in a state of reabsorption. Table I shows the frequency of each stadium and the range of the body weight, mantle length and gonad width of the females tested. There was not a direct relation between maturity stage and the gonad width. Moreover, there was not correlation $(\mathrm{R}=$ 0.3404 ) between the female weight and gonad width.

Stage 1. Immature (Fig. 2A). Oogonia predominately attached to the ovarian stroma, oocyte in developing state can also be observed. The oogonia shapes are spherical with lack of follicle cells. The oviducts and oviductal glands are feebly developed. 


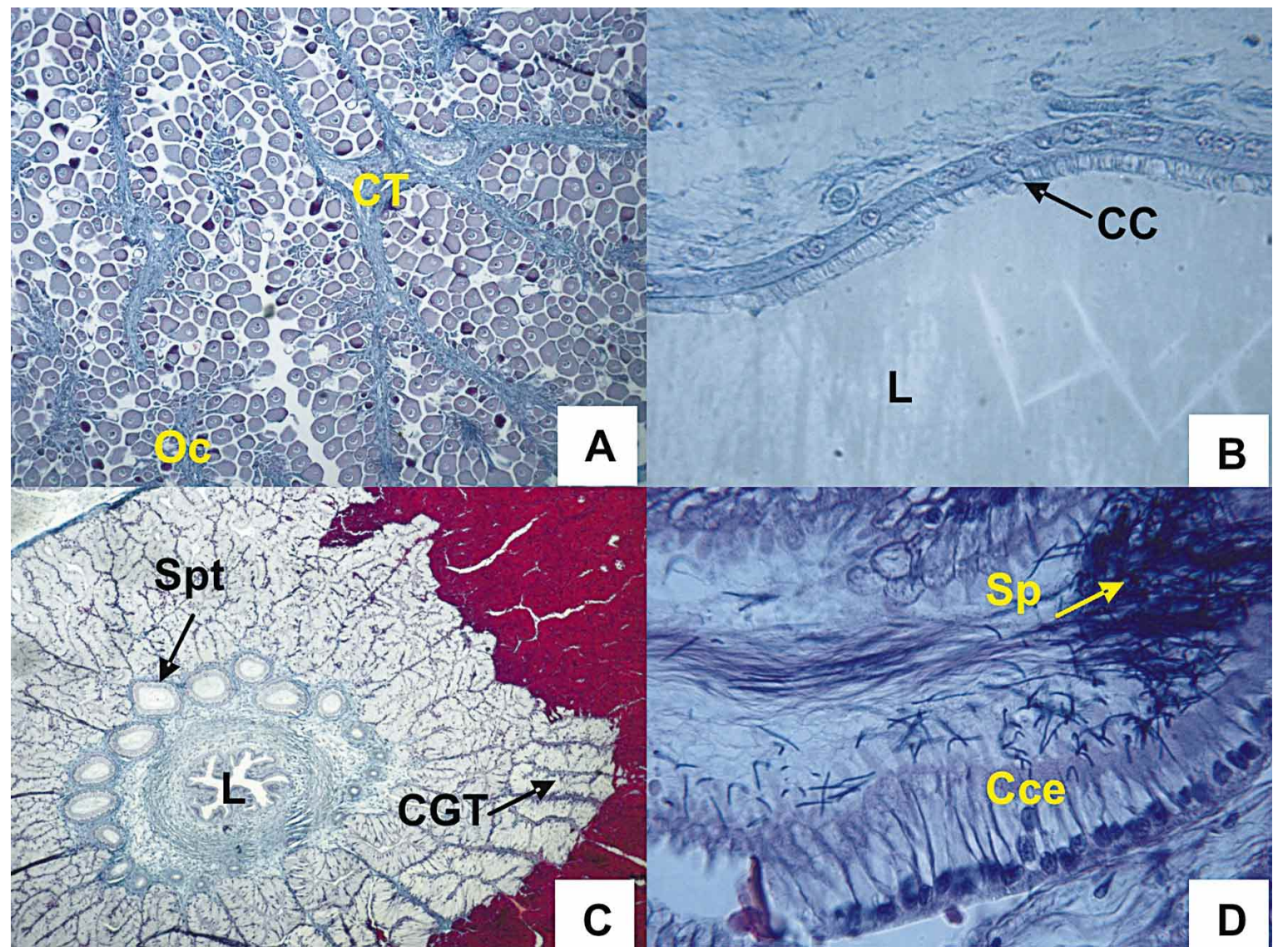

Fig. 1. Female reproductive system of Octopus rubescens. A, cross section of a region of the ovary, 40x, Arteta-trichrome. $\mathrm{B}$, longitudinal section of the ciliated epithelium of the oviduct, 400x. C, transversal section of the oviductal gland, 100x. D, longitudinal section of a spermathecae, 400x. CT, connective tissue; Oc, oocyte; CC, ciliate cells; L, lumen; Spt, spermathecae; CGT, central glandular tissue; Cce, ciliated columnar epithelium; Sp, sperm. Arteta-trichrome.

Stage 2. Initial folliculogenesis (Fig. 2B). Formation of pseudostratified follicular epithelium or secondary follicle that consists of flat cells. Some eggs have polyhedral shapes.

Stage 3. Final folliculogenesis (Fig. 2C). Initial invagination process of the oocyte membrane and the cells lining it. The stroma is confined to the cortical region of the ovary and the oogonia are difficult to observe because of the massive oocyte growth.

Stage 4. Previtelogenesis (Fig. 2D). Oocytes with deep invaginations in their membrane, which is surrounded by follicular cells. Lipid inclusions can be observed and the nuclei are not easily observed.

Stage 5. Early vitelogenesis (Fig. 2E). Yolk granules are seen inside the eggs and their size increased considerably compared to earlier stages. Invaginations remain deep in the follicles, and oocytes form resembles an oval.
Stage 6. Final vitelogenesis (Fig. 2F). The appearance of the yolk is homogeneous, granules are not seen. The follicle invaginations are shallow and very close to each other.

Stage 7. Mature (Fig. 2G). Most of the oocytes have been ovulated from their ovarian follicle. The chorion is formed and the eggs are ready to be fertilized and spawned. Oviductal glands are well developed, like the oviducts.

Stage 8. Spawned (Fig. 2H). Predominate of postovulatory follicles and oocyte reabsorption.

\section{Anatomical description of the male reproductive system.} The gonad in an immature state is white-yellow; when the degree of maturation increases it turns into a whitish color. The testicle is an oval shape (Fig. 3A). The sperm duct is a very thin organ, is less than $1.5 \mathrm{~mm}$ in diameter and is more coiled and compacted. When extended, its length is very similar to the total body length of the octopus (Fig. 3B) and 


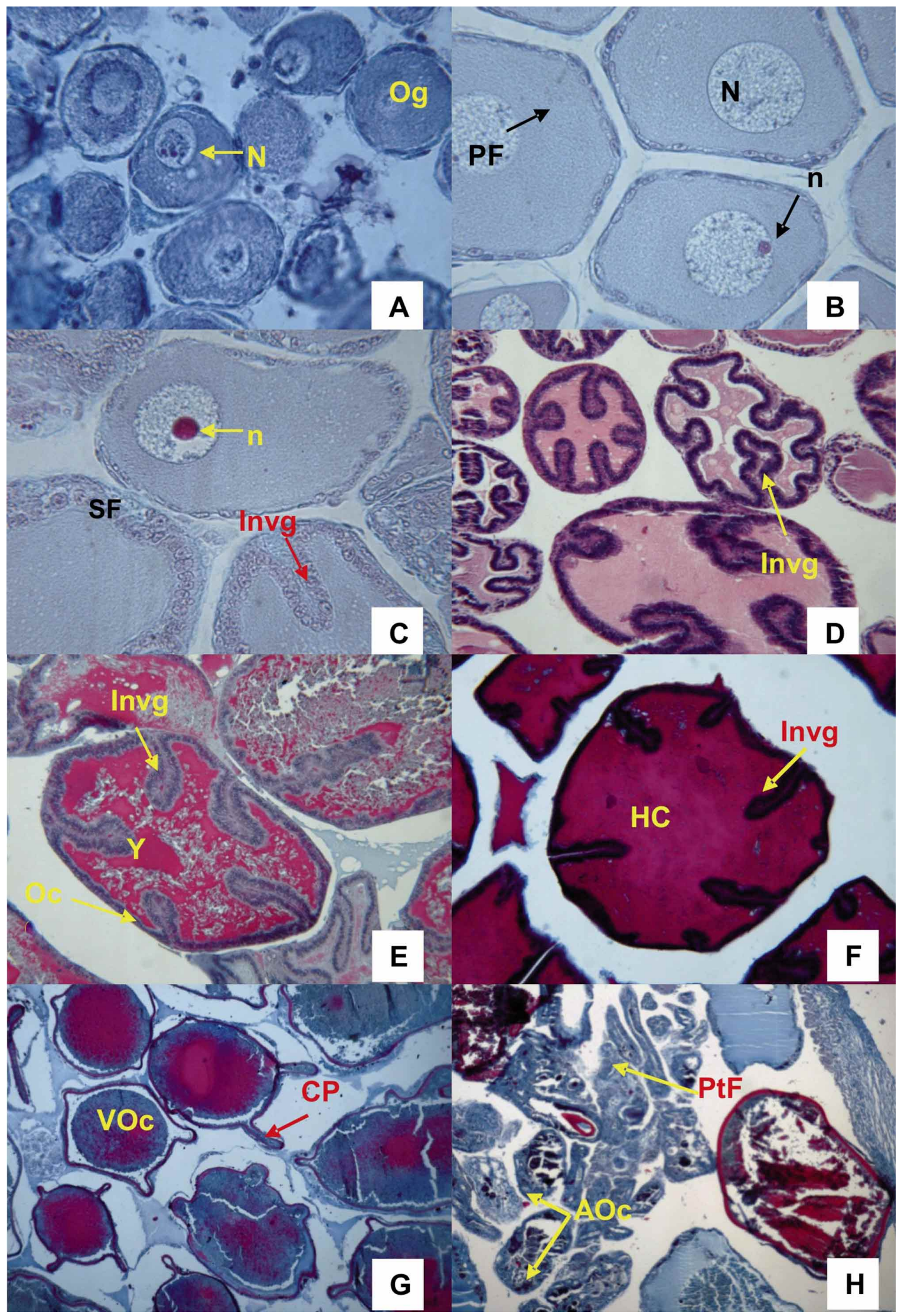




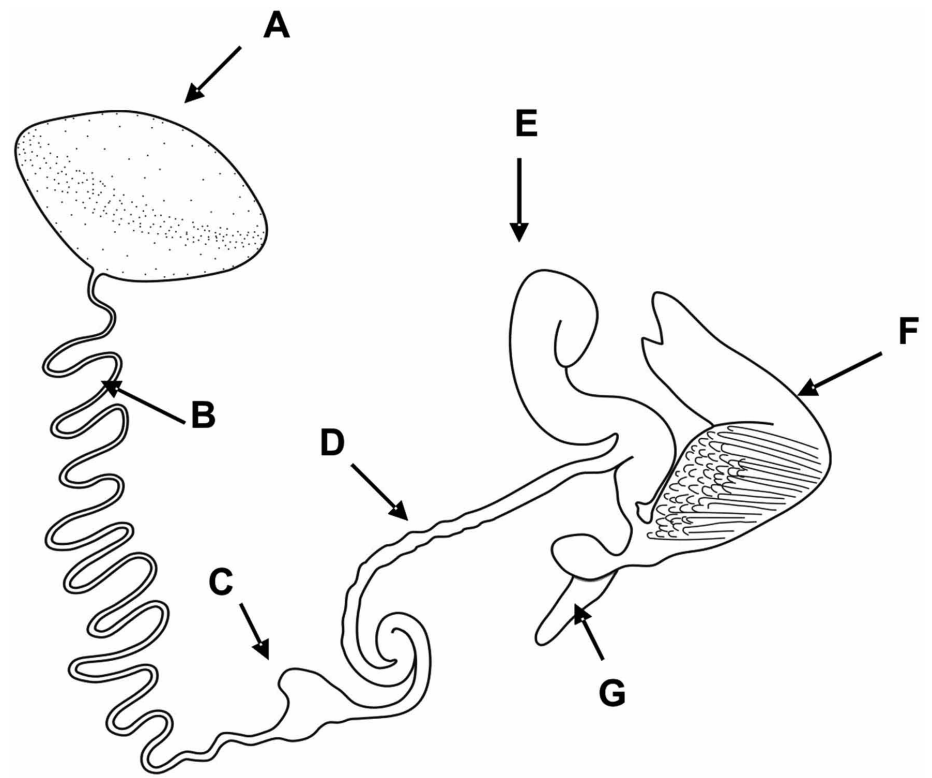

Fig. 3. General diagram of the male Octopus rubescens reproductive system: A, testis; B, spermatic duct; $\mathrm{C}$, proximal portion of the spermatophoric gland; D, distal portion of the spermatophoric gland; E, accessory spermatic gland: F, Needham's sac; G, excurrent duct.

Table I. Intervals of total wet weight of dissected octopus, mantle length (ML) and gonad width (GW) for each maturation stage.

\begin{tabular}{|c|c|c|c|c|c|}
\hline & $\begin{array}{l}\text { Number of } \\
\text { organis ms }\end{array}$ & $\begin{array}{l}\text { Maturity } \\
\text { stage }\end{array}$ & $\begin{array}{l}\text { Weight } \\
\text { range (g) }\end{array}$ & $\begin{array}{c}\text { ML } \\
(\mathbf{m m})\end{array}$ & $\begin{array}{c}\text { GW } \\
(\mathbf{m m})\end{array}$ \\
\hline \multirow{8}{*}{ 总 } & 1 & 1 & 26 & 36.9 & 18.8 \\
\hline & 7 & 2 & $13.5-66.6$ & $14.3-51.0$ & 5.4-9.9 \\
\hline & 5 & 3 & $9.4-54.7$ & $16.4-29.5$ & $5.4-17.7$ \\
\hline & 5 & 4 & $9.9-52$ & $24.5-63.4$ & $6.6-13.9$ \\
\hline & 4 & 5 & $41-48.2$ & $46.5-52.1$ & $13.4-28.2$ \\
\hline & 3 & 6 & $15.7-58.8$ & $33.5-64.5$ & $9.3-24.1$ \\
\hline & 4 & 7 & $22.8-87.7$ & $33-59.4$ & $10.2-28.7$ \\
\hline & 1 & 8 & 32.2 & 47.4 & 18.4 \\
\hline \multirow{5}{*}{$\sum^{\frac{\omega}{E}}$} & 6 & 1 & $9.4-43.5$ & $14.2-50.6$ & $4.4-20.1$ \\
\hline & 7 & 2 & $7.2-25.9$ & $20.2-38$ & 7.6-11.9 \\
\hline & 7 & 3 & $6.7-64.4$ & 23.9-60.4 & $9.9-18.4$ \\
\hline & 7 & 4 & $33.5-188.6$ & $40.0-171$ & $13.0-24$ \\
\hline & 9 & 5 & $24.2-543.4$ & $27.6-95.0$ & $6.1-27.7$ \\
\hline
\end{tabular}

Fig. 2. Octopus rubescens ovary in different maturation stages. A, Stage 1. Immature, 400x. B, Stage 2. Initial folliculogenesis, 400x. C, Stage 3. Final Folliculogenesis, 400x. Arteta-trichrome. D, Stage 4. Previtelogenesis, details of the membrane invaginations of the oocyte, lipid inclusions are seen in the cytoplasm, 100x. Hematoxylin-eosin. E, Stage 5. Initial vitelogenesis, oocytes with deep invaginations, in the follicle and yolk granules in the cytoplasm, 100x. F, Stage 6. Final vitelogenesis, state were oocytes are with smooth cytoplasm and narrow invaginations 100x. G, Stage 7. Mature, here we can see the eggs chorion projections, 40x magnifications; H, Stage 8. Spawned. Arteta-trichrome. Og; oogonia; Oc, oocytes; VOc, vitelate oocytes; N, nucleus; n, nucleolus; PF, primary follicle; SF, secondary follicle; Invg, secondary follicle invaginations; Y, yolk; HC, homogeneous cytoplasm; CP, Chorion projections; AOc, athretic oocytes; PtF, postovulatory follicles. 


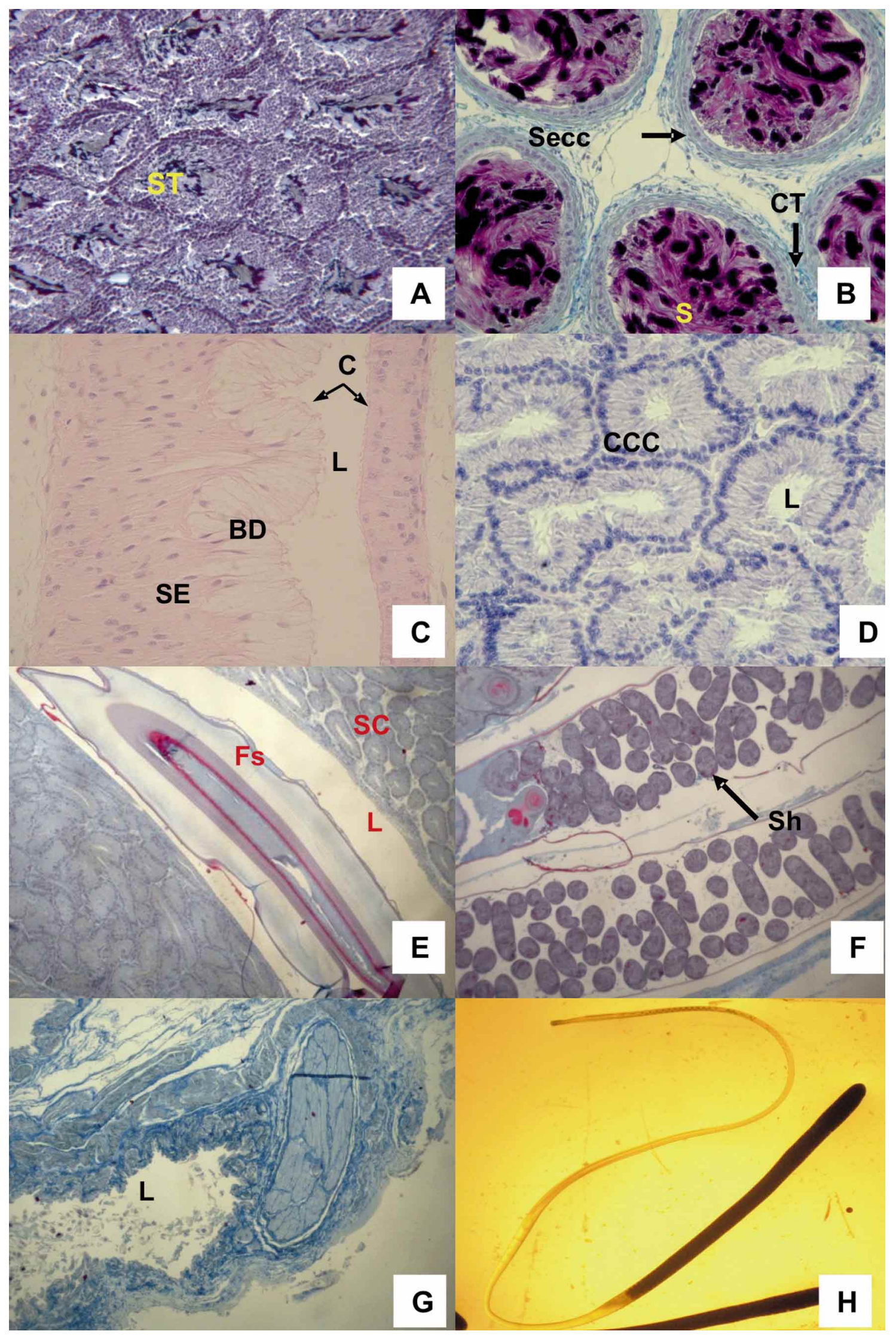


connects the testicle with the spermatophoric gland (Fig. 3, $\mathrm{C}$ and $\mathrm{D})$. The proximal segment of the gland is wide at this point, then the gland coils, decreases its width, instead the distal segment, is a small tube extended into the proximal ends of the accessory spermatic gland (Fig. 3E), that communicate with the Needham's sac (Fig. 3F); the store site for spermatophores. The Needham's sac has a direct communication with the excurrent duct (Fig. 3G), which has an opening in the final portion to release the spermatophores.

\section{Histological description of the male reproductive system.} The testis is wrapped in an albuginea tunica of connective tissue made up of numerous seminiferous tubules, where spermatogenesis takes place (Fig. 4A). Sperm maturation is sequentially from the tubular basement membrane to the central region, where they are discharged into the spermatic duct, which consists of a simple epithelium of ciliated cubic cells, surrounded by connective tissue, mainly collagen fibers (Fig. $4 \mathrm{~B})$. It is possible that the function of this duct consists in compacting sperm in a cylindrical structure, observed in a helical arrangement within the mature spermatophores in the Needham's sac. Through this duct, sperm reaches the spermatophoric gland that has a tubular shape with folds inside. The proximal and distal region of the gland consist of one pseudostratified ciliated epithelium, with very high columnar cells that has a bulbous dilation in contact with the lumen; and a pseudostratified ciliated epithelium with unicelular glands and no bulbose dilatations (Fig. 4C). The middle section of the gland is formed by a number of secretory units composed of ciliated columnar cells with basal nuclei (Fig. 4D). Thereafter, the spermatophore in maturing state passes through the proximal portion of the accessory spermatic gland. This gland is composed of secretory units, consisting of ciliated columnar cells with basal nuclei. The lumen of the gland is ciliated and contains a structure that is dyed bright pink, which is part of the outer casing of the spermatophore (Fig. 4E).

Once spermatophores are mature, they are deposited and stored in parallel to each other in the Needham's sac (Fig. 4F). This organ is composed of simple epithelium with abundant ciliated folds along its structure, surrounded by connective tissue mainly composed of collagen. The spermatophores are cylindrical in shape (Fig. 4G), within a cluster of sperm that are highly compacted and arranged in a helix. Excurrent duct consists of smooth muscle and its lumen is ciliated, it is possible that the octopus hectocotylus arm enters in this organ to extract the spermatophores (Fig. $4 G)$.

We consider five maturity stages based on cell types and their proportions, abundance of connective tissue, immature spermatophores present in the glands and mature spermatophores in Needham's sac, among others. Table I shows the frequency of each maturity stage, body weight range, mantle length and the width of the male gonads analyzed. As in females, we did not found any correlation $(\mathrm{R}=0.7389)$ between weight range and gonad width.

Stage 1. Immature. Seminiferous tubules are small but well defined and delimited by connective tissue. Spermatogonia predominate, although there are also few spermatocytes at the center of the tubulae (Fig. 5A).

Stage 2. Maturing A. One can observe spermatogonia, spermatocytes, spermatids and also there is abundant sperm in the lumen of the seminiferous tubules (Fig. 5B). Still no sperm is seen outside the testicle.

Stage 3. Maturing B. All cell types are present, with a huge amount of sperm in the center of the tubulae. There are sperms in the spermatic duct (Fig. 5C) and there are also spermatophores in the accessory spermatic and spermatophoric gland. However, still there are not spermatophores in Needham's sac.

Stage 4. Mature type 1. All cell types are present, but sperm is the most abundant. Sperm is frequently found in the spermatic duct forming spermatophores in the spermatic gland and the accessory spermatic gland. Abundant mature spermatophores stored in the Needham' sac were observed (Fig. 4F).

Fig. 4. Sections of the male reproductive system of Octopus rubescens and the image of a spermatophore. A, cross section of the testis, there are numerous seminiferous tubules, 100x. B, transverse section of the spermatic duct, 200x. Artetatrichrome. C, distal section of the spermatophoric gland, 400x, Hematoxylin-eosin. D, intermediate region of the spermatophoric gland, consisting of secretory cells, 400x, Arteta- trichrome. E, longitudinal section of the accessory spermatic gland, 40x Arteta-trichrome. F, longitudinal section of Needham's sac with spermatophores stored, 40x. G, distal excurrent duct, 40x, Arteta-trichrome. H, spermatophore. ST, the seminiferous tubule; Secc, simple epithelium of ciliated cuboidal cells; CT, connective tissue; S, sperm; PE, pseudoestratified epithelium with dilatación bulbosa (DB); C, cilia; L, lumen; SC, secretory cells; CCC, ciliated columnar cells with basal nuclei; Fs, formation of the spermatophore cover ; Sh, spermatophore. 


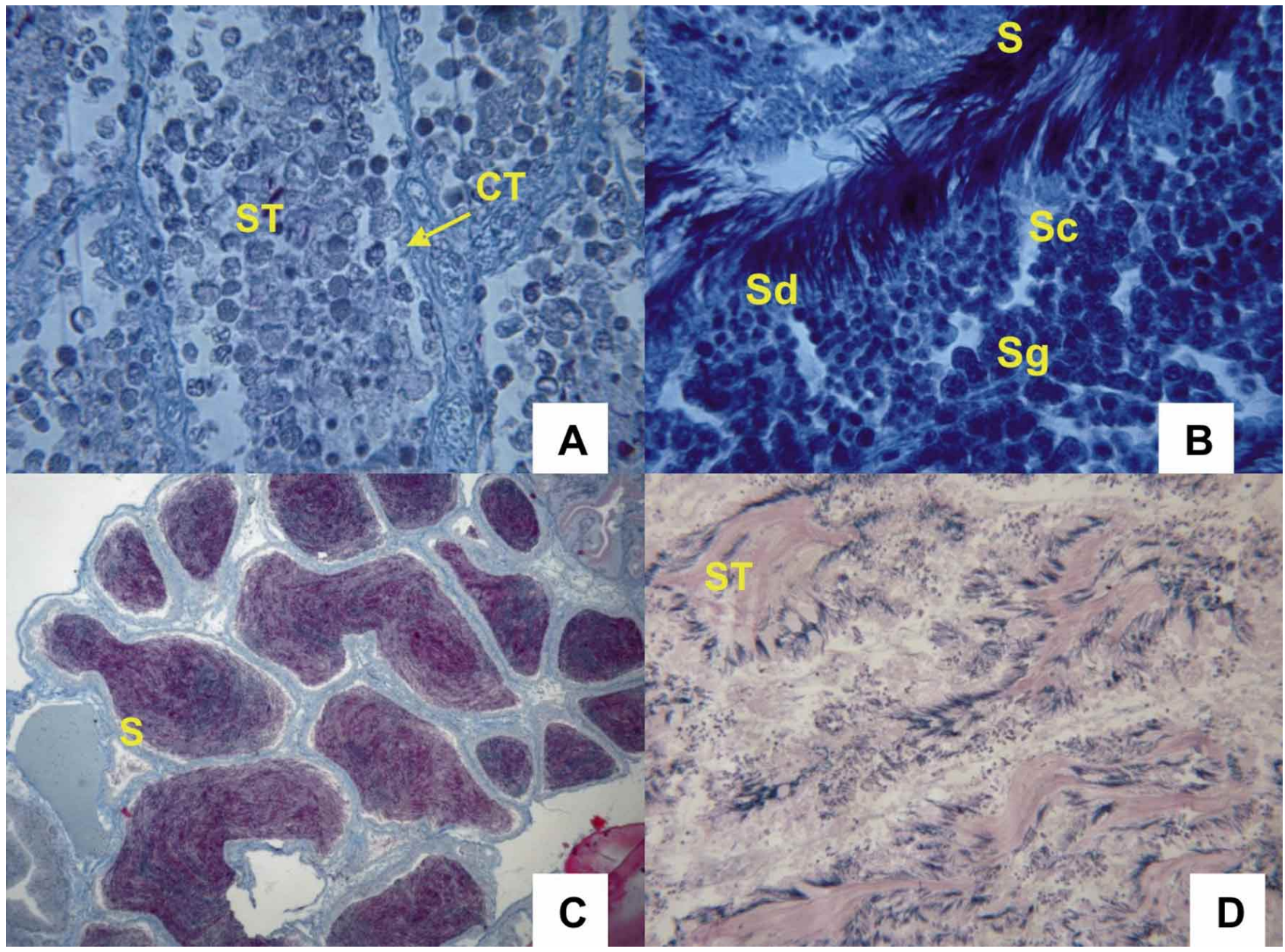

Fig. 5. Sections of the male reproductive system. A longitudinal section of an immature male testes, 400x. B, section of seminiferous tubules showing all cell types, 400x. C, section of the spermatic duct with sperm, 100x, Arteta trichrome. D, section of the testis with seminiferous tubules disorganized, 100x, Hematoxylin-eosin. ST, seminiferous tubules; Sg, spermatogonia; Sc, spermatocytes; Sd, spermatids; S, sperm; CT, connective tissue.

Stage 5. Mature type 2. The seminiferous tubules have a limp look and deteriorated. Few spermatogonia are observed; even in some organisms seem to be missing. The sperm, though few compared to Stage 4, are predominant at this stage (Fig. 5D). There are abundant spermatophores in the Needham's sac.

\section{DISCUSSION}

This work is novel because there is not enough basic biological information of the main species distributed in the region of Ensenada, Mexico, and is the first histological description of the reproductive system of the octopus $O$. rubescens.
An observation of the general morphology of the female reproductive system of $O$. rubescens coincides with those described by Olivares-Paz et al., in O. mimus. In contrast, Price observed in $O$. bimaculoides that the common oviduct emerges from inside the ovary. In $O$. rubescens, the common oviduct is divided to form a pair of oviducts, which are observed in the oviductal glands in an arrangement similar to that of $O$. vulgaris (Wells, 1978), O. mimus (Olivares-Paz et al.) and E. cirrhosa (Alvarez-Perez \& Haimovici). The female reproductive systems of different species of cephalopods do not have the same structure. In the myopsid squid as in cuttlefish and cirrine octopuses, it consists of a single ovary and an oviduct with oviductal gland (Budelmann et al., 1997, Boyle \& Rodhouse). The reproductive system of the cuttlefish is more complex than that of the octopuses; the oviductal glands are situated in 
the distal end of oviduct; they also have accessory and nidamental glands (Arkipkin).

Histological analysis of the anatomy of the reproductive system of the octopus can explain the maturation process of gametes and precisely define the stage of gonad maturity. The ovary of $O$. rubescens is similar to $O$. bimaculoides, $O$. mimus and $O$. vulgaris (Price; JiménezBadillo et al.). Staining techniques used in this research, did not allow identifying the types of substances secreted in the oviductal gland tissues. However, Froesch \& Marthy (1975) and Grubert \& Wadley (2000) were able to identify through conventional staining methods, the secretion of a mucoprotein in the peripheral tissue of the oviductal gland which serves to fix the eggs to the substrate, while the central region secretes a mucopolysaccharide that polymerizes the mucoprotein (Boyle \& Rodhouse).

We confirmed the presence of spermathecaes in the oviductal glands, as others researchers have found in the genus Octopus (Froesch \& Marthy; Grubert \& Wadley; Rodriguez-Rua et al.), nevertheless in some specimens, sperm were observed stored. The genus Eledone lack a spermathecae, therefore the sperms are maintained in the cavity of the ovary, which is the site for eggs fertilization (Froesch \& Marthy; Budelmann et al.; Boyle \& Rodhouse). This site does not exist in other species of cephalopods such as Vulcanuptopus hydrothermales because the females have no spermathecae in the oviductal glands and neither sperm were observed in the ovarian cavity (González et al., 2008). Loliginid's and some oegopsid, store the sperm in the mouth, while the cuttlefish and sepiolid squid stored them in the mantle cavity (Budelmann et al.).

The oocyte maturation process is very similar in female cephalopods. The distinctive and peculiarity in the oogenesis of these species, is the formation of a second layer of follicular cells and the follicular invagination, which generate the yolk secretion (Boyle \& Knobloch). Although there is much discrepancy in the number of stages established and nomenclature assigned, most studies agree on a stage for the secondary follicle formation, and subsequently the formation of the chorion (Boyle \& Knobloch; Arkhipkin; Gabr et al., 1998; Olivares-Paz et al.; Rodriguez-Rua et al.; Boyle \& Rodhouse; Jiménez-Badillo et al.).

This work was carried out with female body weights less than $100 \mathrm{~g}$, and we found the smallest mature female weighing $22.8 \mathrm{~g}$, and a spawned female of $33.2 \mathrm{~g}$. Most authors who have studied the sexual maturity in species such as $O$. vulgaris and $O$. mimus (Rodriguez-Rua et al.; Leporati et al.; Jiménez-Badillo et al.), have been working with mature females weighing more than $200 \mathrm{~g}$, in these species, females reaches a greater average weight than in $O$. rubescens, which can mature at much smaller sizes.

The male reproductive system is complex because in addition to form sperms, they are embedded in spermatophores with a very complicated design. Various authors differ in the nomenclature of the organs (Price; Álvarez-Pérez \& Haimovici; Arkhipkin; Budelmann et al.; Boyle \& Rodhouse), except for the testis and the Needham's sac. Price described the spermatic duct as an interchangeably proximal vas deferens or spermatic duct; while Boyle and Rodhouse, indicate that the distal region of this organ is located between the spermatophoric gland and the accessory spermatic gland. Price indicates that the spermatic duct or distal vas deferens is communicating the accessory spermatic gland with the Needham's sac, which coincides with the observation made by Álvarez-Pérez \& Haimovici, Arkhipkin and Budelmann et al. This cannot be corroborated in this work because we did not make histological sections of the regions indicated by these authors.

In relation to the glands that constitute the male reproductive system of the octopus, some authors such as Álvarez-Pérez \& Haimovici, Boyle (1991), Budelmann et $a l$. and Boyle and Rodhouse, describe the spermatophoric gland and accessory spermatic gland as glandular system I and II, respectively. Budelmann et al., called this gland as seminal vesicle, and prostate to the accessory spermatic accessory gland. However, it is not appropriate to refer to these glands under these terms, because the presence of secretions of substances in the seminal fluid has not been proved and the existence of the secretion of some kind of mucus is only assumed. In general, the seminal fluid is used to keep the liberated sperms alive in organisms with internal fertilization.

The terminal organ of the male reproductive system has been called penis (Leporati et al.). In the present study we adopted the nomenclature proposed by Boyle and Knobloch, and Boyle and Rodhouse, who define this organ as excurrent duct because it has no intromittent function. In some squid species (Onychoteuthis $s p$.) the terminal organ of the male reproductive system is very long and functions as a penis (Arkhipkin).

Although the male reproductive system is very complex and there is a large discrepancy in the nomenclature of their anatomic components, structurally there is greater uniformity among the species of cephalopods, compared with females (Arkhipkin).

Histologically, the testis of $O$. rubescens has a tubular structure, as it is clearly seen that the spermatogoniae are associated with the tubular basement membrane and the 
different maturation stages of spermatocytes are sorted into the lumen, so it is possible to observe all maturation stages in any section of the tubulae. Several authors agree with this description (Budelmann et al.; Olivares-Paz et al.), and other authors have observed that this tissue is composite by haemolinphatic vessels and interstitial cells (Price). In contrast, Ishiyama et al. (1999), did not observe seminiferous tubules in the testis of $O$. mimus but they found folds into the wall of the gonad where spermatogenesis takes place. The histological structure of the spermatic duct of $O$. rubescens coincides with that described by Price for $O$. bimaculoides and also with the description of the spermatophoric gland, which is very complex, and its anatomy varies longitudinally. In addition, the general morphology and histology of the Needham's sac described by this author agrees with that observed in samples of $O$. rubescens.

The shapes of the $O$. rubescens mature spermatophore is very complex and anatomically concur with what was described for O. dofleini martini (Boyle; Boyle \& Rodhouse). Spermatophores may be evacuated by peristaltic muscle tissue through the excurrent duct (Price). Importantly, not all cephalopods produce spermatophores, for example Incirrina octopuses' forms sperm packages that are less complex than the spermatophores (Arkhipkin).

Most of the studies about the process of sexual maturation in octopus males basically establish four stages: immature, maturing, mature and without spermatophores. The characteristic commonly used to determine that an organism is ripe, is the presence of spermatophores stored in the Needham's sac (Ezzeddine-Najai; Moriyasu; OlivaresPaz et al.; Rodríguez-Rua et al.; Jiménez-Badillo et al.).

Several male reproductive studies in different species of octopus agree that male mature faster than females (Boyle \& Knobloch; Silva et al., 2004; Rodríguez-Rua et al.; Akyol et al., 2007; Leporati et al.), which is consistent with the observations of this study, where the smallest mature male was $6.7 \mathrm{~g}$, and the smallest mature female $22.8 \mathrm{~g}$.

Histological examination is a long and impractical procedure to establish the degree of sexual maturation in the field, however, is the most reliable tool to accurately define the maturity stage of an organism.

This paper provides a detailed description of the macroscopic and microscopic structure of the reproductive system of $O$. rubescens. In addition we propose a simple microscopic scale that can be used to determine the maturity degree of the organisms, which can be used in subsequent investigations.

\section{AKNOWLEDGEMENTS}

This work was supported by the Federal Government of México with regular funding of the Centro de Investigación Científica y de Educación Superior de Ensenada (C.I.C.E.S.E.) Project 623151.

LÓPEZ-PERAZA, D. J.; HERNÁNDEZ-RODRÍGUEZ, M.; BARÓN-SEVILLA, B. \& BÜCKLE-RAMIREZ, L. F. Análisis histológico del aparato reproductor y la madurez gonadal del pulpo Octopus rubescens. Int. J. Morphol., 31(4):1459-1469, 2013.

RESUMEN: En el presente estudio se describió el aparato reproductor y el desarrollo gonadal del pulpo Octopus rubescens de la Bahía de Todos Santos en Baja California, México. Se realizó la descripción macroscópica del aparato reproductor de hembras y machos y se caracterizó cada una de las partes que lo integran. Para la descripción del desarrollo gonadal se utilizaron las técnicas histológicas de Hematoxilina-Eosina y la tinción tricrómica de Arteta. Se analizaron histológicamente un total de 65 organismos de los cuales 35 machos tuvieron un intervalo de peso de 7,2 a 543,4 g y las 30 hembras de 9,4 a 87,7 g. La escala de madurez en las hembras se caracterizó con ocho estadios: 1. Inmaduro, 2. Foliculogénesis inicial, 3. Foliculogénesis final, 4. Previtelogénesis, 5. Vitelogénesis inicial, 6. Vitelogénesis final, 7. Maduros y 8. Desovados. En los machos se identificaron cinco estadios: 1. Inmaduro, 2. En maduración A, 3. En maduración B, 4. Maduro tipo 1 y 5. Maduro tipo 2. Este trabajo constituye la primera descripción histológica del aparato reproductor de esta especie y sienta las bases para futuras investigaciones sobre su biología básica.

PALABRAS CLAVE: Octopus rubescens; Histología; Sistema reproductivo; Maduración gonadal.

\section{REFERENCES}

Akyol, O.; Sen, H. \& Kınacigil, H. T. Reproductive biology of Eledone moschata (Cephalopoda: Octopodidae) in the Aegean Sea (Izmir Bay, Turkey). J. Mar. Biol. Ass. U. K., 87(4):967-70, 2007.
Álvarez-Pérez, J. A. \& Haimovici, M. Sexual Maturation and Reproductive Cycle of Eledone massyae, Voss 1964 (Cephalopoda: Octopodidae) in Southern Brazil. Bull. Mar. Sci., 49(1-2):270-9, 1991. 
Arkhipkin, A. T. Reproductive System Structure, Development and Function in Cephalopods with a New General Scale for Maturity Stages. J. Northwest Atl. Fish. Sci., 12:63-74, 1992.

Boyle, P. R. The care and management of cephalopods in the laboratory. UFAW Handbook. Longmam, Harlow, 1991. p.63.

Boyle, P. R. \& Knobloch, D. Male Reproductive Maturity in the Octopus, Eledone cirrhosa (Cephalopoda: Octopoda). J. Mar. Biol. Ass. U. K., 64(3):573-9, 1984.

Boyle, P. R. \& Rodhouse, P. Cephalopods. Ecology and Fisheries. Oxford, Blackwell, 2005. p.452.

Budelmann, B. U.; Schipp, R. \& Boletzky, S. V. Cephalopoda. En: Harrison, F. W. \& Kohn A. J. (Eds.). Microscopic Anatomy of Invertebrates. Vol. 6A. New York, Wiley-Liss, 1997. pp.119-414.

Carta Nacional Pesquera. INAPESCA-SAGARPA. Mexico, 2010.

Ezzeddine-Najai, S. Maturation sexuelle d'Eledone moschata (Cephalopoda, Octopoda) du golfe de Gabes (Tunisie, Méditerranée Orientale). Vie è Milieu, 47(1):69-76, 1997.

Froesch, D. \& Marthy, H. J. The structure and function of the oviducal gland in octopods (Cephalopoda). Proc. R. Soc. Lond. B, 188:95110,1975

Gabr, H. R.; Hanlon, R. T.; Hanafy, M. H. \& El-Etreby, S. G. Maturation, fecundity and seasonality of reproduction of two commercially valuable cuttlefish Sepia pharaonis and $S$. dollfusi, in the Suez Canal. Fish. Res., 36(2-3):99-115, 1998.

González, A. F.; Guerra, A.; Pascual, S. \& Segonzac, M. Female description of the hydrothermal vent cephalopod Vulcanoctopus hydrothermalis. J. Mar. Biol. Ass. U. K., 88(2):375-9, 2008.

Grubert, M. A. \& Wadley, V. A. Sexual Maturity and Fecundity of Octopus maorum in Southeast Tasmania. Bull. Mar. Sci. 66(1):131-42, 2000.

Iglesias, J. \& Sánchez, F. J. La diversificación en moluscos cefalópodos: El pulpo (Octopus vulgaris). Sesión Temática Diversificación. IX Congreso de Acuacultura, Vigo, España, 2007.

Ishiyama, V.; Siga, B. \& Talledo, C. Biología Reproductiva del Pulpo Octopus mimus (Mollusca: Cephalopoda) de la Región de Matarani, Arequipa, Perú. Rev. Peru. Biol., 6(1), 1999. Disponible en: http:// sisbib.unmsm.edu.pe/bvrevistas/biologia/v06_n1/bio_repro.htm

Jiménez-Badillo, M. L.; del Río-Rodríguez, R. E.; Gómez-Solano, M. I.; Cu-Escamilla, A. \& Méndez-Aguilar, D. Madurez gonádica del pulpo Octopus vulgaris en el Golfo de México: análisis macroscópico y microscópico. Universidad Autónoma de Campeche, 2008. p.48.

Khallahi, O. M. F. \& Inejih, C. A. O. Proposition d'une echelle macroscopique de maturite sexuelle des femelles de poulpe Octopus vulgaris (Cuvier, 1797). Vol. XXIX. Bulletin Scientifique de l'Institut Mauritanien de Recherches Océanographiques et des Pêches, 2002.

Lang, M. A. \& Hochberg, F. G. Proceedings of the Workshop on The fishery and Market Potential of Octopus in California. Washington, Smithsonian Institution, 1997. p.192.
Lee, P. G. Nutrition of cephalopods: fueling the system. Mar. Fresh. Behav. Physiol., 25:35-51, 1994.

Leporati, S. C.; Pecl, G. T. \& Semmens, J. M. Reproductive status of Octopus pallidus, and its relationship to age and size. Mar. Biol., 155(4):375-85, 2008

Moriyasu, M. Analyse de la maturation sexuelle d'Eledone cirrhosa (Cephalopoda:Octopoda) du Golfe du Lion. Aquat. Living Res., 1:5965, 1988.

Olivares-Paz, A.; Zamora-Covarrubias, M.; Portilla-Reyes, P. \& ZuñigaRomero, O. Estudio histológico de la ovogénesis y maduración ovárica en Octopus mimus (Cephalopoda: Octopodidae) de la II región de Chile. Estud. Oceanol., 20:13-22, 2001.

Petza, D.; Katsanevakis, S. \& Verriopoulos, G. Experimental evaluation of the energy balance in Octopus vulgaris, fed ad libitum on a highlipid diet. Mar. Biol., 148:827-32, 2006.

Price, P. The anatomy and histology of the reproductive systems of Octopus bimaculoides. Department of Zoology. California, Pomona College, 1959. p.26.

Rodríguez-Rúa, A.; Pozuelo, I.; Prado, M.; Gómez, M. J. \& Bruzón, M. A. The gametogenic cycle of Octopus vulgaris (Mollusca: Cephalopoda) as observe on the Atlantic coast of Andalusia (South of Spain). Mar. Biol., 147:927-33, 2005.

SEMARNAP. Estadísticas pesqueras básicas. Dir. Gral. de Informática y Reg. Pesq. México, 1999. p.125.

Silva, L.; Ramos, F. \& Sobrino, I. Reproductive biology of Eledone moschata (Cephalopoda: Octopodidae) in the Gulf of Cadiz (Southwestern Spain, ICES Division IXa). J. Mar. Biol. Ass. U. K., 84:12216, 2004.

Valderrama, K.; Oliva, M.; Campos, B. \& Brown, D. Parasitic castration of Eurhomalea lenticularis (Bivalvia: Veneridae) by a digenetic trematode: quantitative histological analysis. Dis. Aquat. Organ., 59(2):151-8, 2004.

Wells, M. J. Octopus Physiology and Behaviour of an Advanced Invertebrate. London, Champman and Hall, 1978. p.335.

\section{Correspondence to:}

M. Hernández-Rodríguez

Deparment of Aquaculture, P.O.

Box: 434844 , San Diego

CA. 921434844

USA

\section{Email: mhernand@cicese.mx}

Received: 12-04-2013

Accepted: 11-08-2013 